\title{
Prediction of Bankruptcy in selected Steel Sector Companies in India using Financial Ratios
}

\author{
Effulgence \\ Vol. 17, No. 1 \\ January - June 2019 \\ Rukmini Devi Institute of Advanced Studies \\ E-mail : effulgence@rdias.ac.in, Website : www.rdias.ac.in \\ http://effulgence.rdias.ac.in/user/default.aspx \\ https://dx.doi.org/10.33601/effulgence.rdias/v17/i1/2019/16-27
}

\author{
Dr. Saurabh Agarwal $^{1} \measuredangle \Delta$ \\ Dr. Megha Agarwal ${ }^{2}$
}

\section{Abstract}

An attempt has been made to use ratio analysis and logistic regression for Predicting insolvency and bankruptcy. The paper extensively reviews existing literature to find out how financial distress can be predicted using ratios. Alternate methodologies and their uses have also been outlined. Finally, Logistic regression model has been developed based on select financial ratios. The model has been empirically tested on Indian Steel sector.

Keywords: Distress diagnosis, Discriminant, Corporate bankruptcy risk, financial ratio analysis. JEL: G33, C49, C88.

\section{INTRODUCTION}

$\mathbf{I}_{\mathrm{n}}^{\mathrm{n}}$ n the present Indian corporate context with large number of firms failing to honor their commitments towards their stakeholders and applying for bankruptcy, it becomes imperative for the academic world to provide the industry with a model to predict such bankruptcy. We need to identify study and analyze the potential indicators of corporate bankruptcy and develop a system whereby prediction of bankruptcy is made possible. This paper is an attempt to bridge this gap and help the investors, bankers, government agencies, other stakeholders of companies and general public in predicting the financial health of the firm before taking their decision.

Accounting and Financial ratios provide extensive historical information on past decisions as well as about future events, to stakeholder's part of the company and external to a firm.

1. Professor of Accounting and Finance, Indian Institute of Finance, Greater Noida, UP, India, sa@iif.edu

2. Assistant Professor, Rajdhani College, University of Delhi, Delhi, India, megha_dse@yahoo.co.in 
Traditionally, financial analysts have been using trend analysis, horizontal analysis and vertical analysis for analyzing the financial statements. Accounting experts recommend the use of ratios for analyzing financial statements. Recently, a lot of literature has been written on the use of Economic Value Added (EVA) for understanding the sustain ability of enterprises. Rudimentary methods of identifying trends, intra-industry analysis, and comparison with industry averages, inter-industry analysis and use of arbitrary standards have played a limited role in predicting bankruptcies in companies. Du-pont analysis also aids to understand the entities financial health by focusing on the interrelationship between ratios. Non-financial considerations like environmental performance, corporate social responsibility initiatives also provide a picture of the future sustain ability of the enterprise.

\section{REVIEW OF LITERATURE}

Failures of companies like LTCM and Enron point out to the potential destabilizing effect of derivative markets on companies. The impact of derivatives on potential bankruptcy needs to be analyzed. Works by Bolton and Oehmke (2015) provide an insight on relationship between Derivatives and Bankruptcy?

Leland and Toft (1996) have examined bankruptcy from the perspective of capital structure. Corporates have to strike a balance between bankruptcy costs and the tax deductibility of debt. They even created an endogenous bankruptcy trigger to determine the optimal leverage. They found that bankruptcy can be determined endogenously depending upon the amount and maturity of debt.

Altman (1968) predicted financial distress in firms using multiple discriminant analysis. Firms were divided into two mutually exclusive groups. The discriminant function was based on five ratios which described the overall index $\mathrm{Z}$. To test the overall discriminating power of the model, $\mathrm{F}$ test was used. t-test was used to test the significance of the results.
With reasonable accuracy one is able to predict bankruptcy using Altman Z score Model. The paper became the foundation paper for many more researchers to work in this virgin area.

Castanias (1983) examined the relationship between bankruptcy and leverage ratios. They found that capital structure decision is a relevant decision for maximizing the value of the firm. Using Kendall and Pearson correlation coefficients failure rates were related to eight financial ratios. The study focused on smaller firms. It was found that optimal level of leverage depends upon default costs and business risk.

Johnson (1970) commented on the works in ratio analysis that predict bankruptcy. Cash flow to total debt ratio was found to be the single best ratio for predicting corporate bankruptcy by Beaver's (1966, 1968). Altman (1969) found five ratios. Trend and volatility analysis based on financial ratios was undertaken by Blum (1969). He criticized the existing models as ratios are based on historical financial statements. In ex-ante framework ratios fail to provide the economic processes that predict the failure of firms. Secondly, ratios suffered from different accounting treatments in financial statements and are only meaningful if they can be measured against a standard. Finally, it was observed that ratios are unable to describe the dynamic process of a firm failure. He recommended the need for a decision model that can provide dynamic analysis to predict failure.

Altman, Haldeman and Narayanan (1977) developed a "Zeta Analysis" model based on changes in financial reporting standards. Their study resulted identifies seven new variables explaining corporate failure. Study has used Multiple Discriminant analysis. It was recommended that alternate discriminant models having either in linear or quadratic form are suitable for different sectors. Blum (1974) developed a failing company model using 12 variables. The firms were matched in the two groups on the basis of annual sales, number of 
employees, industry and fiscal year. Edmister's (1972) work developed a discriminant function based on seven variables found out of 19 ratios. He focused on the interaction effect of level and trends. He focused on (1) the level of ratios compared to industry averages, (2) three-year trends, (3) five-year averages of ratios, and (4) combined effect of industry relative trend and industry relative level. Taffler's (1984) worked on a sample of 50 financial ratios and avoided multi-collinearity using principal component analysis. Five ratios were finally outlines that could predict bankruptcy.

Gilbert, Menon and Schwartz (1990) using multinomial logit technique created a model that could predict that a financially distressed firm would survive or go bankrupt. Persons (1999) using logistic models found that failing firms can be predicted based on liquidity, management quality, asset quality, earning ability and capital adequacy.

Laitinen and Laitinen (2000) developed a bankruptcy prediction model based on Taylor's series expansion model and logistic regression model. Important factors affecting insolvency included shareholder's equity to total assets, cash flow to total assets and the cash to total assets ratios. A firm is likely to be bankrupt if it has large financial obligations, low cash inflows and large net cash flow.

Gupta (1983) has developed a model for prediction of bankruptcy. His analysis was based on 56 ratios. Non-parametric test were conducted to measure the differentiating power of financial ratios. He found that cash flow to sales, earnings before depreciation interest and tax to sales, earnings before interest and tax to total assets and cash flow to total assets could predict financial distress in textile industry.

Kaveri (1983) recommended that current ratio, net worth to total liabilities, stock turnover ratio and net worth to fixed assets ratios can be used for prediction of bankruptcy. Paranjape (1980) found that Retained earnings to total assets, Raw materials consumed to sales, Retained earnings to total assets,
Inventory to current assets and Earnings before interest and tax to total liabilities can predict financial sickness with 90 percent accuracy.

Ramakrishnan (2003) in in his doctoral work on distress prediction analysis reviewed manufacturing firms. He used a total of 11 variables for prediction of bankruptcy. He analyzed his model using both Multivariate discriminant analysis (MDA) and Logit Analysis. Both the models had similar predictive power for future financial distress. However, MDA wrongly identified the firms as distressed for two firms. It was found that predictive ability was there for one year in advance. Long term forecast could not be made for the sample firms. Cash flow and working capital were identified as important predictors of bankruptcy. Since the model can predict bankruptcy one year in advance, the bankers and non-banking financial services can use this model to predict possible NPAs and companies can also initiative the revival process.

\section{METHODOLOGY}

Academicians and corporates have developed many sophisticated statistical financial distress models to predict bankruptcy. Most of the models have been based on (a) univariate analysis, (b) multivariate or multiple discriminant analysis (MDA) analysis, (c) logit regression analysis and (d) neural network computing system.

Uni-variate models focus on the predictive power of a single variable to predict bankruptcy. Beaver's study $(1966,1968)$ is an example of univariate analysis where cash flow to debt ratio was found to be the most optimal ratio for predicting bankruptcy. Altman's MDA model (1968) is an example of multivariate analysis and has been empirically tested by many authors like Martin (1977) and Altman and Lavalle (1981), Taffler (1984), Hamer (1983), Lincoln (1984), Suominen (1988) and Bhatia (1988) and Koh and Killough (1990). Recent studies have used logistic regression analysis to predict bankruptcy as it is able to overcome the limitations posed by MDA. 
Many researchers like Ohlson (1980), Zavgren (1983), Dhumale (1998), Zhongsheng, Hua, Yu Wang, XiaoyanXu, BinZhang and Liang Liang (2007) have followed logistic analysis for predicting bankruptcy. Many other scholars like Hansen \& Messier (1991), Tam \& Kiang (1992), Coats \& Fant (1993) and Etheridge \& Sriram (1997) and Khatib, Genanew \& Rao (2018) have focused on artificial intelligence or neural network for predicting financial distress.

The stressed assets of banking and non-banking finance companies have increased manifold during the last decade. Maximum research work on prediction of corporate bankruptcy has been undertaken in countries like USA, UK, Greece, France and Finland. Hence, this still remains a virgin area of research in India and a valuable academic input for corporates. Initially, researchers used MDA and recently used logistic regression analysis. Many other methods like Linear probability models, probit analysis, recursive partioning algorithm, survival analysis, univariate analysis and expert system exists and have their own merits and de-merits. The benefits and shortcomings of use of Logit regression analyses has been explained by Martin (1977), Ohlson (1980) and Ramakrishnan (2003) and have not been reproduced here. The paper has use logistic regression analysis for prediction of bankruptcy.

\section{Data \& Bankruptcy Prediction Model}

The sample consists of two groups of 5 firms each (bankrupt and non-bankrupt group). The bankruptcy group (1) is steel companies that were referred to bankruptcy proceeding by RBI during 2017-18. To study the prediction of bankruptcy using accounting ratios, ten companies from the steel sector have been included in the model. The sample includes both bankrupt as well as non-bankrupt firms. The average total assets of the companies included over the last three years 2015-2018 has been shown in Table 1 . The average size of the companies is Rs. 37765 crores, ranging between Rs. 9000 crores to Rs. 88000 crores. Bankruptcy status is a categorical variable where one depicts a bankrupt firm while zero depicts a non-bankrupt firm. Group 2 consisted of firms selected on the basis of asset size. Both the groups have firms which are operating on a going concern basis. The data for the empirical analysis has been extracted from CMIE prowess. It is quite unique to India that such large asset size steel firms have undergone bankruptcy. Large size firm bankruptcy poses significant challenges related to Bank NPAs, Unemployment and loss of tax revenue. Hence, this pivotal question has been investigated in this research paper.

Table 1: Bankruptcy Status and Asset Size of the Firms

\begin{tabular}{|l|c|c|}
\hline Company Name & Bankruptcy Status & Total Assets \\
\hline Bhushan Power \& Steel Ltd. & 1 & 45882.32667 \\
\hline Bhushan Steel Ltd. & 1 & 61967.49667 \\
\hline Electrosteel Steels Ltd. & 1 & 11487.85667 \\
\hline Essar Steel India Ltd. & 1 & 68453.81333 \\
\hline J S W Steel Ltd. & 0 & 88640.13 \\
\hline Jindal Stainless Ltd. & 0 & 12874.39 \\
\hline Monnet Ispat \& Energy Ltd. & 1 & 9906.33 \\
\hline Posco Maharashtra Steel Pvt. Ltd. & 0 & 9273.513333 \\
\hline Rashtriya Ispat Nigam Ltd. & 0 & 29390.83 \\
\hline Uttam Galva Steels Ltd. & 0 & 9779.056667 \\
\hline & & 34765.57433 \\
\hline
\end{tabular}


Past studies have identified a number of variables; a list of 18 variables represents the possible predictors of bankruptcy. The variables have been selected on the basis previous in-depth work by Altman (1968) and Ramakrishnan (2003) and "new" ratios becoming popular in academic research.

In the present corporate scenario with high amounts of current liabilities leading to negative working capital, negative earnings before interest and taxes, negative profits and negative cash flows many ratios calculated lost their relevance. They have not been included in empirical testing. The remaining positive ratios have also been pruned based on their multicollinearity. From the initial list of eighteen ratios finally four ratios were finally selected and found most suitable as predictors of corporate bankruptcy in large steel firms.

In simple terms the corporate bankruptcy predictor model is represented by outcome (B) is predicted from a combination of each predictor variable $(X)$ multiplied by its respective regression coefficient $(\alpha)$ :

$B_{i}=a_{0}+a_{1} X 1+a_{2} X 2+\ldots . .+a_{n} X n i+\varepsilon_{i} \quad$ equation 1

The Logistic regression equation from which the probability of $\mathrm{B}$ is predicted is given by

$$
P(B)=1 / 1+e^{-\left(a 0+a 1 \times 1+a 2 x_{2}+\ldots .+a n X n i+c_{i}\right)} \quad \text { equation } 2
$$

\section{Where,}

\begin{tabular}{|c|c|}
\hline X1: WC/TA & $=$ Working capital $/$ Total assets same as WC/TA \\
\hline X2: RE/TA & Retained Earnings/Total assets \\
\hline X3: EBIT/TA & Earnings before interest and taxes/Total assets \\
\hline X4: MV/BV & Market value equity/Book value of total debt \\
\hline X5: S/TA & Sales/Total assets \\
\hline X6: NP I TA & Profit after Taxes / Total Assets \\
\hline X7: CF / CL & [Profit after Taxes + Depreciation] / Current Liabilities \\
\hline X8: CF / TL & [Profit after Taxes + Depreciation] / Total Liabilities \\
\hline X9: EBIT / S & Earnings Before Interest and Taxes I Sales \\
\hline X10: CA / CL & Earnings Before Interest and Taxes I Sales \\
\hline X11: CA / TA & Current Assets / Total Assets \\
\hline X12: S/CA & Sales / Current Assets \\
\hline $\mathrm{X} 13: \mathrm{CF} / \mathrm{CE}+\mathrm{D}$ & $\begin{array}{l}\text { Cash from operating activities/Capital expenditure }+ \text { Dividends paid (Cash } \\
\text { adequacy ratio) }\end{array}$ \\
\hline X14: CF/CL & Cash from operating activities/Current liabilities (Cash flow ratio) \\
\hline X15: NCL/ CF & Non-current liabilities/Cash from operating activities (Debt coverage ratio) \\
\hline $\mathrm{X} 16: \mathrm{CF} / \mathrm{S}$ & Cash from operating activities/Net sales (Cash flow to sales ratio) \\
\hline X17: FCF & $\begin{array}{l}=\text { Cash from operating activities - Capital investments for PPE (Plant, Property and } \\
\text { Equipment) to maintain existing operations (Free cash flow) }\end{array}$ \\
\hline X18: EVA & $\begin{aligned}= & \text { NOPAT }-(\text { Total Assets }- \text { Current Liabilities) * WACC (Weighted Average Cost of } \\
& \text { Capital) }\end{aligned}$ \\
\hline
\end{tabular}

X1 to X5 given by Altman (1968), X6 to X12 outlined by Ramakrishna (2003) and X13 to X18 identified by the researchers based on their popularity in academic research. 


\section{EMPIRICAL RESULTS \& ANALYSIS}

Initially seventeen ratios for the sample companies have been calculated. The ratio of market value of equity to book value of debt could not be calculated due to paucity of availability of data. All the other ratios have been calculated first individually for three years 2015, 2016 and 2017 and also for average accounting data of these three years. The ratios based of averages of the three years have been presented in Table 2.

Table 2: Variable Means for sample testing

\begin{tabular}{|c|c|c|c|c|c|c|c|c|c|c|c|c|c|c|c|c|c|}
\hline Company Name & $\begin{array}{c}\text { AA1 }= \\
\text { WC/TA } \\
2015 \\
\end{array}$ & $\begin{array}{l}\mathrm{AA} 2= \\
\mathrm{RE} / \mathrm{TA}\end{array}$ & $\begin{array}{c}\mathrm{AA} 3=\mathrm{EB} \\
\mathrm{IT} / \mathrm{TA}\end{array}$ & $\begin{array}{c}\text { AA5 }= \\
\text { SALES } \\
/ \text { TA }\end{array}$ & $\begin{array}{l}\text { AA6= } \\
\text { NP/TA }\end{array}$ & $\begin{array}{l}\mathrm{AA} 7= \\
\mathrm{CF} / \mathrm{CL}\end{array}$ & $\begin{array}{l}\mathrm{AA} 8= \\
\mathrm{CF} / \mathrm{TL}\end{array}$ & $\begin{array}{c}\text { AA9 }= \\
\text { EBIT } / \mathrm{S} \\
\text { ALES }\end{array}$ & $\begin{array}{l}\mathrm{AA} 10= \\
\mathrm{CA} / \mathrm{CL}\end{array}$ & $\begin{array}{l}\mathrm{AA} 11= \\
\mathrm{CA} / \mathrm{TA}\end{array}$ & $\begin{array}{c}\text { AA12= } \\
\text { SALES } \\
/ \text { TA }\end{array}$ & $\begin{array}{c}\text { AA13= } \\
\text { SALES } \\
/ \text { CA }\end{array}$ & $\begin{array}{c}\text { AA14= } \\
\text { Cash } \\
\text { Adequac } \\
\text { y Ratio }\end{array}$ & $\begin{array}{l}\text { AA15 = } \\
\text { Cash } \\
\text { Flow } \\
\text { Ratio }\end{array}$ & $=\mid \begin{array}{c}\mathrm{AA} 16=\mathrm{De} \\
\text { bt } \\
\text { coverage } \\
\text { ratio }\end{array}$ & $\begin{array}{l}\text { AA167 }= \\
\text { Cash } \\
\text { flow to } \\
\text { sales } \\
\text { ratio } \\
\end{array}$ & $\begin{array}{c}\text { AA18 }= \\
\begin{array}{c}\text { Free cash } \\
\text { flow }\end{array}\end{array}$ \\
\hline Bhushan Power \& Steel Ltd. & -0.171 & -0.024 & -0.033 & 1.226 & -0.024 & -0.018 & -0.005 & -0.174 & 0.375 & 0.103 & 0.188 & 1.835 & -1.183 & 0.174 & 13.035 & 0.252 & 4019.030 \\
\hline Bhushan Steel Ltd. & -0.287 & -0.056 & -0.067 & 0.098 & -0.056 & -0.076 & -0.032 & -0.290 & 0.229 & 0.085 & 0.231 & 2.709 & -1.992 & 0.035 & 38.584 & 0.056 & 1215.137 \\
\hline Electrosteel Steels Ltd. & -0.656 & -0.231 & -0.239 & 0.126 & -0.231 & -0.251 & -0.167 & -0.896 & 0.160 & 0.125 & 0.267 & 2.141 & -1.895 & 0.073 & 6.927 & 0.214 & 1000.733 \\
\hline Essar Steel India Ltd. & -0.315 & -0.072 & -0.080 & 0.031 & -0.072 & -0.100 & -0.061 & -0.282 & 0.283 & 0.124 & 0.285 & 2.294 & -12.946 & 0.073 & 8.806 & 0.112 & 2356.423 \\
\hline IS W Steel Ltd. & -0.078 & 0.013 & 0.026 & -1.670 & 0.018 & 0.190 & 0.085 & 0.043 & 0.709 & 0.191 & 0.615 & 3.228 & -2.058 & 0.369 & 3.363 & 0.161 & 12679.75 \\
\hline Windal Stainless Ltd. & -0.006 & -0.005 & -0.005 & 1.214 & -0.005 & 0.052 & 0.026 & -0.007 & 0.983 & 0.359 & 0.700 & 1.953 & -32.624 & 0.523 & 1.952 & 0.273 & 2533.567 \\
\hline Monnet Ispat \& Energy Ltd. & -0.312 & -0.174 & -0.174 & 0.026 & -0.174 & -0.286 & -0.141 & -1.080 & 0.352 & 0.170 & 0.161 & 0.947 & -4.496 & 0.042 & 24.696 & 0.125 & 242.827 \\
\hline Posco Maharashtra Steel Pvt. Ltd. & -0.116 & 0.016 & 0.016 & -0.231 & 0.016 & 0.105 & 0.069 & 0.024 & 0.765 & 0.379 & 0.673 & 1.774 & -35.527 & 0.264 & 1.912 & 0.195 & 1249.947 \\
\hline Rashtriya Ispat Nigam Ltd. & -0.190 & -0.047 & -0.058 & 1.207 & -0.047 & -0.064 & -0.045 & -0.134 & 0.532 & 0.216 & 0.430 & 1.987 & -0.019 & 0.003 & 136.595 & 0.003 & 2083.863 \\
\hline Uttam Galva Steels Ltd. & -0.486 & -0.081 & -0.101 & 0.113 & -0.081 & -0.081 & -0.064 & -0.204 & 0.284 & 0.193 & 0.494 & 2.562 & -4.367 & 0.074 & 3.702 & 0.101 & 600.653 \\
\hline
\end{tabular}

The working capital of all of the companies is negative (current liabilities are greater than current assets) hence a negative working capital to total assets ratio is arrived at. All the other such negative ratios are excluded from further testing. Hence, only six ratios were left namely current assets to current liabilities, current assets to total assets, sales to total assets, sales to current assets, cash flow ratio and debt coverage ratio. Tests for multicollinearity shows high degree of correlation between both the current asset based ratios and both the sales based ratios. Hence, only one ratio based on current assets and one based on sales was included. The final ratios included in the binary logit model are current assets to current liabilities, sales to total assets, cash flow ratio and debt coverage ratio.

The model testing is using the financial ratios data for the year 2015 to predict bankruptcy in the late of 2017 i.e two years prior to the event. SPSS 20 has been used for the purpose of model testing. Table 3 presents the variable values for the four independent variables and the categorical dependent variable.

Table 3: Testing for bankruptcy 2015, 2 years prior -Dependent and Independent Variables for Model Testing

\begin{tabular}{|l|l|l|l|l|l|}
\hline \multicolumn{1}{|c|}{2015} & $\begin{array}{l}\text { Categorical } \\
\text { Variable }\end{array}$ & AA10=CA/CL & $\begin{array}{l}\text { AA12= } \\
\text { SALES/TA }\end{array}$ & $\begin{array}{l}\text { AA15 } \\
\text { =Cash } \\
\text { Flow } \\
\text { Ratio }\end{array}$ & $\begin{array}{l}\text { AA16=Debt } \\
\text { coverage } \\
\text { ratio }\end{array}$ \\
\hline Company Name & $\begin{array}{l}\text { Bankruptcy } \\
\text { Status }\end{array}$ & & & & \\
\hline Bhushan Power \& Steel Ltd. & 1 & 0.42 & 0.18 & 0.32 & 7.34 \\
\hline Bhushan Steel Ltd. & 1 & 0.22 & 0.21 & 0.05 & 35.05 \\
\hline Electrosteel Steels Ltd. & 1 & 0.27 & 0.22 & 0.17 & 11.31 \\
\hline
\end{tabular}




\begin{tabular}{|l|l|l|l|l|l|}
\hline Essar Steel India Ltd. & 1 & 0.37 & 0.22 & 0.02 & 40.00 \\
\hline J S W Steel Ltd. & 0 & 0.62 & 0.49 & 0.26 & 5.37 \\
\hline Jindal Stainless Ltd. & 0 & 1.34 & 0.45 & 0.14 & 9.67 \\
\hline Monnet Ispat \& Energy Ltd. & 1 & 0.60 & 0.19 & 0.18 & 8.34 \\
\hline $\begin{array}{l}\text { Posco Maharashtra Steel Pvt. } \\
\text { Ltd. }\end{array}$ & 0 & 0.71 & 0.53 & 0.02 & 36.69 \\
\hline Rashtriya Ispat Nigam Ltd. & 0 & 0.55 & 0.46 & 0.07 & 5.02 \\
\hline Uttam Galva Steels Ltd. & 0 & 0.42 & 0.68 & 0.14 & 2.74 \\
\hline
\end{tabular}

The binary logit model with the four ratios current assets to current liabilities, sales to total assets, cash flow ratio and debt coverage ratio were able to predict bankruptcy two years in advance i.e. in year 2015 for the firms which were declared bankrupt in the year 2017. The Cox and Snell R square of the model is 0.750 which indicate that 75 percent of the variance is predicted by the four independent variables chosen. The model is a good fit for bankruptcy. Table 4 shows the output of the model. The model is robust at ten percent level of significance.

It is further tested whether or model is able to predict bankruptcy one year in advance and in the year of the actual event of failure of the firm.

Table 4: 2015 Bankruptcy Prediction Model Results

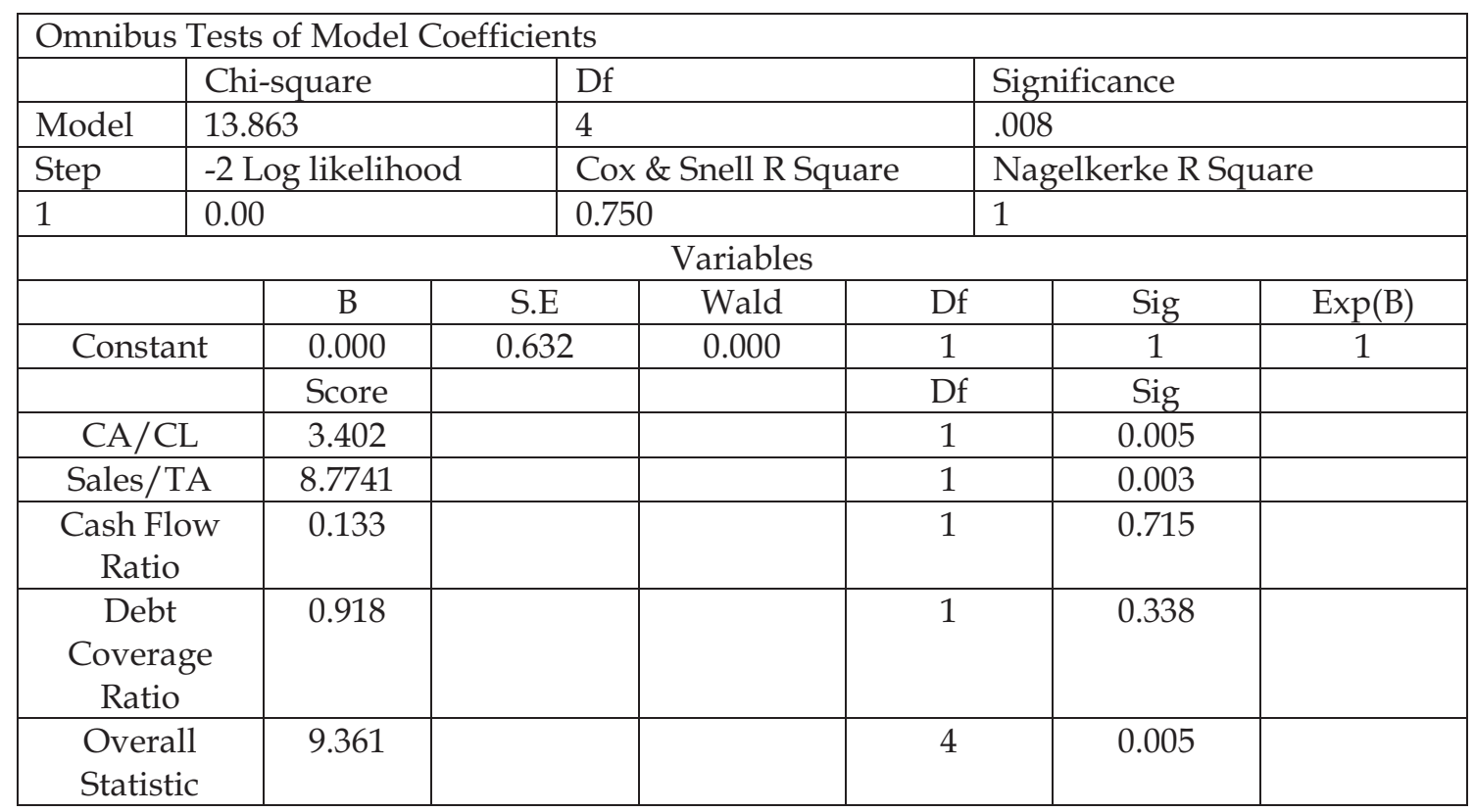


Table 5: Testing for Bankruptcy 2016, 1 years Prior - Dependent and Independent Variables

\begin{tabular}{|l|l|l|l|l|l|}
\hline Company Name & $\begin{array}{l}\text { Bankr } \\
\text { uptcy } \\
\text { Status }\end{array}$ & $\begin{array}{l}\text { AA10=C } \\
\text { A/CL }\end{array}$ & $\begin{array}{l}\text { AA12= } \\
\text { SALES/ } \\
\text { TA }\end{array}$ & $\begin{array}{l}\text { AA15 } \\
\text { =Cash } \\
\text { Flow Ratio }\end{array}$ & $\begin{array}{l}\text { AA16=Debt } \\
\text { coverage } \\
\text { ratio }\end{array}$ \\
\hline Bhushan Power \& Steel Ltd. & 1 & 0.36 & 0.19 & 0.10 & 21.61 \\
\hline Bhushan Steel Ltd. & 1 & 0.23 & 0.24 & 0.03 & 40.75 \\
\hline Electrosteel Steels Ltd. & 1 & 0.15 & 0.21 & 0.03 & 26.68 \\
\hline Essar Steel India Ltd. & 1 & 0.25 & 0.32 & 0.09 & 6.09 \\
\hline J S W Steel Ltd. & 0 & 0.70 & 0.64 & 0.34 & 3.34 \\
\hline Jindal Stainless Ltd. & 0 & 0.67 & 0.78 & 1.03 & 0.66 \\
\hline Monnet Ispat \& Energy Ltd. & 1 & 0.27 & 0.15 & 0.00 & -286.95 \\
\hline $\begin{array}{l}\text { Posco Maharashtra Steel Pvt. } \\
\text { Ltd. }\end{array}$ & 0 & 0.79 & 0.74 & 0.38 & 1.17 \\
\hline Rashtriya Ispat Nigam Ltd. & 0 & 0.52 & 0.42 & -0.03 & -18.19 \\
\hline Uttam Galva Steels Ltd. & 0 & 0.34 & 0.45 & 0.05 & 5.31 \\
\hline
\end{tabular}

Table 6: 2016 Bankruptcy Prediction Model Results

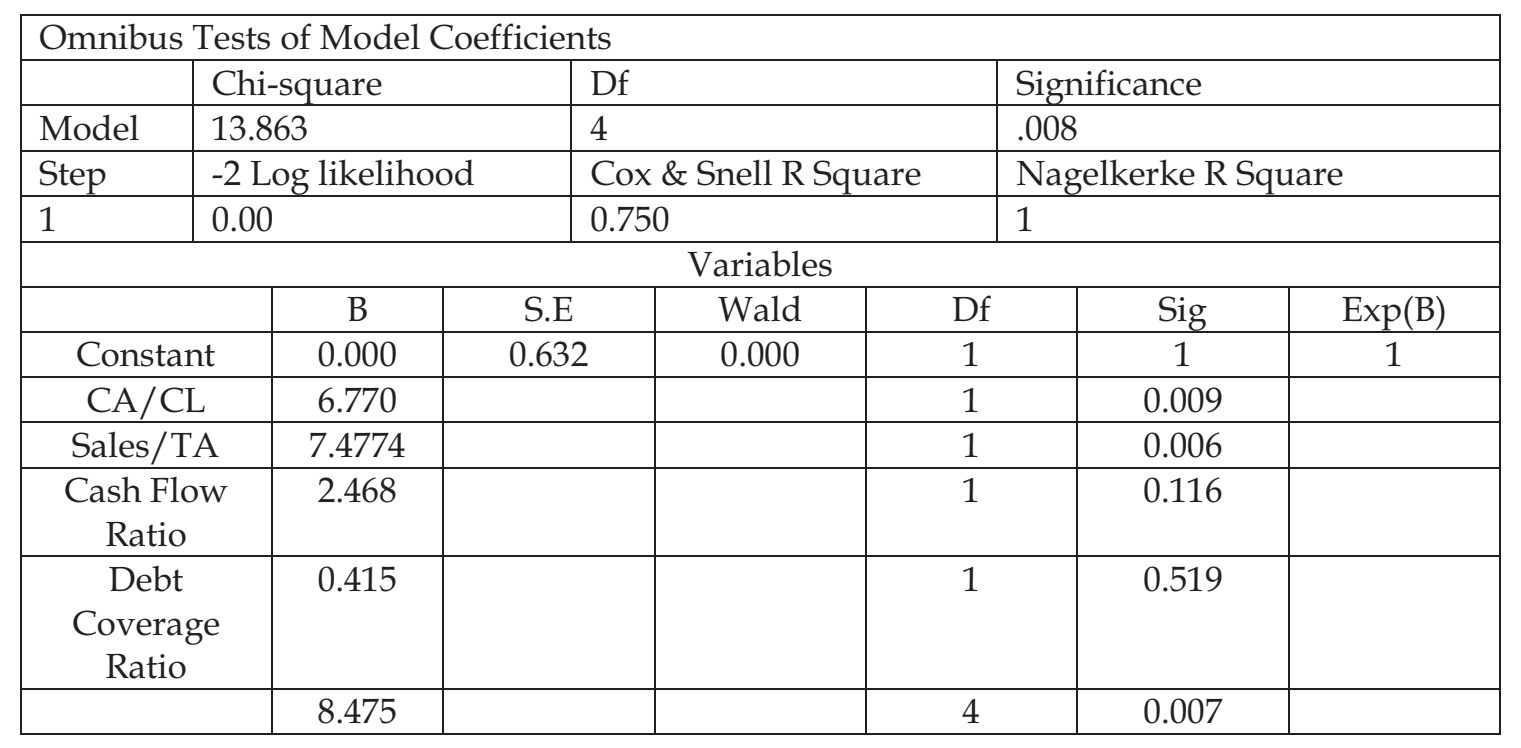

Table 7: Testing for Bankruptcy 2017, Year of Bankruptcy - Dependent and Independent Variables

\begin{tabular}{|l|l|l|l|l|l|}
\hline Company Name & $\begin{array}{l}\text { Bankruptc } \\
\text { y Status }\end{array}$ & $\begin{array}{l}\text { AA10 } \\
=\text { CA/ } \\
\text { CL }\end{array}$ & $\begin{array}{l}\text { AA1 } \\
2= \\
\text { SAL } \\
\text { ES/T } \\
\text { A }\end{array}$ & $\begin{array}{l}\text { AA15 } \\
\text { =Cash } \\
\text { Flow Ratio }\end{array}$ & $\begin{array}{l}\text { AA16=Debt } \\
\text { coverage ratio }\end{array}$ \\
\hline Bhushan Power \& Steel Ltd. & 1 & 0.36 & 0.19 & 0.10 & 21.61 \\
\hline Bhushan Steel Ltd. & 1 & 0.23 & 0.24 & 0.03 & 40.75 \\
\hline Electrosteel Steels Ltd. & 1 & 0.13 & 0.44 & 0.07 & 0.00 \\
\hline Essar Steel India Ltd. & 1 & 0.25 & 0.32 & 0.09 & 6.09 \\
\hline
\end{tabular}




\begin{tabular}{|l|l|l|l|l|l|}
\hline J S W Steel Ltd. & 0 & 0.80 & 0.70 & 0.50 & 2.44 \\
\hline Jindal Stainless Ltd. & 0 & 0.90 & 0.96 & 0.38 & 2.52 \\
\hline Monnet Ispat \& Energy Ltd. & 1 & 0.27 & 0.15 & 0.00 & -286.95 \\
\hline $\begin{array}{l}\text { Posco Maharashtra Steel Pvt. } \\
\text { Ltd. }\end{array}$ & 0 & 0.79 & 0.74 & 0.38 & 1.17 \\
\hline Rashtriya Ispat Nigam Ltd. & 0 & 0.52 & 0.42 & -0.03 & -18.19 \\
\hline Uttam Galva Steels Ltd. & 0 & 0.09 & 0.31 & 0.03 & 5.16 \\
\hline
\end{tabular}

Table 5 presents the variable values used for testing the bankruptcy model for the steel sector in the year 2016 for the companies which actually failed in June 2017. Table 6 depicts the model coefficients as derived in SPSS. Again, the Cox and Snell R square is 0.750 . The beta score of two ratios current assets to current liabilities and sales to total assets is significant at ten percent level of significance.
Table 7 presents the variable values used for testing the bankruptcy model for the steel sector in the year 2017 for the companies which were referred for bankruptcy in June 2017 i.e. three months prior. The model was eighty per cent accurate in predicting the bankruptcy. The result is shown in Table 8, the classification table. Eighty percent of companies which were actually declared bankrupt could be predicted to go bankrupt using our model.

Table 8: Classification Table

\begin{tabular}{|c|c|c|c|c|}
\hline \multirow{3}{*}{\multicolumn{2}{|c|}{ Observed }} & \multicolumn{3}{|c|}{ Predicted } \\
\hline & & \multicolumn{2}{|c|}{ Bankruptcy Status } & \multirow{2}{*}{$\begin{array}{c}\text { Percentage } \\
\text { Correct }\end{array}$} \\
\hline & & $\begin{array}{c}\text { Non } \\
\text { Bankrupt }\end{array}$ & Bankrupt & \\
\hline \multirow{2}{*}{$\begin{array}{l}\text { Bankruptc } \\
\text { y Status }\end{array}$} & $\begin{array}{l}\text { Non- } \\
\text { Bankrupt }\end{array}$ & 4 & 1 & 80.0 \\
\hline & Bankrupt & 1 & 4 & 80.0 \\
\hline \multicolumn{2}{|c|}{ Overall Percentage } & & & 80.0 \\
\hline
\end{tabular}

The model summary is given in Table 9. Cox \& Snell $\mathrm{R}$ square and Naelkerke $\mathrm{R}$ Square depict the predictive ability of the bankruptcy prediction model which is 0.532 and 0.710 respectively. The log likelihood statistic shows the deviance from the baseline model which included only a constant term and shows the improvement in the model over the baseline model. Wald Statistic shows the relative contribution of each of the variables in predicting bankruptcy. The odds ratio is depicted as Exp (B) value. An Increase in Current Assets to Current Liabilities Ratio, Sales to Total Assets Ratio will reduce the odds of bankruptcy as the odds ratio is less than one. The relationship between the direction of debt coverage ratio (Non-current liabilities/Cash from operating activities) and the incidence of bankruptcy cannot be ascertained as the odds ratio is very close to one (0.996). 
Table 9: 2017 Bankruptcy Prediction Model Results

\begin{tabular}{|l|r|r|rr|}
\hline Step & -2 Log likelihood & \multicolumn{2}{c|}{$\begin{array}{c}\text { Cox \& Snell R } \\
\text { Square }\end{array}$} & \multicolumn{2}{|c|}{ Nagelkerke R Square } \\
\hline 1 & 6.260 & .532 & & .710 \\
\hline
\end{tabular}

\begin{tabular}{|c|c|c|c|c|c|c|c|}
\hline \multicolumn{8}{|c|}{ Variables } \\
\hline & & B & S.E. & Wald & $\mathrm{df}$ & Sig. & $\operatorname{Exp}(B)$ \\
\hline \multirow{5}{*}{ Step 1} & $\mathrm{CA} / \mathrm{CL}$ & -4.512 & 7.641 & .349 & 1 & .555 & .011 \\
\hline & SALES/TA & -13.908 & 11.316 & 1.511 & 1 & .219 & .001 \\
\hline & $\begin{array}{l}\text { CASH } \\
\text { FLOW } \\
\text { RATIO } \\
\end{array}$ & 9.949 & 14.734 & .456 & 1 & .500 & 20933.909 \\
\hline & $\begin{array}{l}\text { DEBT } \\
\text { COVERAG } \\
\text { E RATIO }\end{array}$ & -.004 & .023 & .033 & 1 & .856 & .996 \\
\hline & Constant & 5.939 & 3.710 & 2.563 & 1 & .109 & 379.531 \\
\hline
\end{tabular}

\section{SUMMARY AND CONCLUSIONS}

The ratios have played a vital role in predicting bankruptcy in advance before it becomes public and they are referred for bankruptcy to the National Company Law Tribunal (NCLT) or the Insolvency and Bankruptcy Board of India (IBBI). Many alternate methodologies exist like Uni-variate analysis, multiple discriminant analysis, Logit regression and neural networks are popular in academic literature for predicting bankruptcy well in advance. The existing models have been tested for their efficiency in predicting bankruptcy from one to five years in advance. The paper develops a theoretical model of how one may use logit regression and select ratios to predict bankruptcy in advance. An empirical analysis was done on companies' part of Indian Steel Sector. It was found that four ratios current assets to current liabilities, sales to total assets, cash flow ratio and debt coverage ratio were able to predict bankruptcy two years in advance and in the year of bankruptcy. The model may be of extreme value for banking sector and non-banking finance companies that may use the model to forecast their possible Non Performing
Assets (NPAs) and take adequate measures well in advance. Also, companies may evaluate their worsening situation and adopt right strategies for restructuring or management change.

\section{REFERENCES}

1) Altman, E. I., 1968, Financial Ratios, Discriminant Analysis and The Prediction of Corporate Bankruptcy, The Journal of Finance 23(4), 589 - 609.

2) Altman, E. I., 1969, Corporate Bankruptcy Potential, Stockholder returns and Share Valuation, The Journal of Finance 24(5), 887-900.

3) Altman, E., and Lavalle, 1981, Business Failure Classification in Canada, Journal of Business Administration.

4) Altman, E.I., R.G. Haldeman and P. Narayanan, 1977, ZETA Analysis A new model to identify Bankruptcy Risk of Corporations, Journal of Banking and Finance 1(1), 29-54.

5) Beaver, W., 1966, Financial Ratios as Predictors of Failure, Empirical Research in Accounting, 71110.

6) Beaver, W., 1968, Alternative Accounting 
Measures as Predictors of Failure, Accounting Review, 46-53.

7) Bhatia, U., 1988, Prediction Corporate Sickness in India, Studies in Banking and Finance 7, 57-71.

8) Blum, Marc, 1969, The Failing Company Doctrine, Unpublished Ph.D. Dissertation (Columbia University, Graduate School of Business, 1969).

9) Blum, M., 1974, Failing Company Discriminant Analysis, Journal of Accounting Research 12(1), 1-25.

10) Bolton, P. and M. Oehmke, Should Derivatives be Privileged in Bankruptcy, The Journal of Finance 70(6), 2353-2394.

11) Castanias, Richard, 1983, Bankruptcy Risk and Optimal Capital Structure, The Journal of Finance 38(5), 1617 - 1635.

12) Coats, Pamela K. \& L. Franklin Fant, 1993, Recognizing Financial Distress Patterns Using a Neural Network Tool, Financial Management 22(3).

13) Dhumale, Rahul, 1998, Earnings Retention as a Specification Mechanism in Logistic Bankruptcy Models: A Test of the Free Cash Flow Theory, Journal of Business Finance and Accounting 25(7-8), 1005-1023.

14) Edmister, Robert O., 1972, An Empirical Test of Financial Ratio Analysis for Small Business Failure Prediction, Journal of Financial and Quantitative Analysis 7(2), 1477-1493.

15) Etheridge \& Sriram (1997)

16) Etheridge, H. and R. Sriram, A comparison of the relative costs of Financial Distress Models, International Journal of Intelligent Systems in Accounting, Finance and Management 6 (3), 235248.

17) Gupta, L.C., 1983, Financial Ratios for Monitoring Sickness, Oxford University Press.

18) Hansen, James and William Messier, 1991, Artificial Neural Networks: Foundations and application to a Decision Problem, Expert Systems with Applications 3, 135-141.

19) Johnson, Craig G., 1970, Ratio Analysis and the Prediction of Firm Failure, The Journal of Finance 25(5), 1166-1168.
20) Kaveri, V.S., 1983, How to Diagnose, Prevent and Cure Industrial Sickness, Sultan Chand and Sons, New Delhi.

21) Al Khatib, M., W. Genanew, \& A. Rao, 2018, Predicting Business Distress Using Neural Network in SME-Arab Region, International Review of Advances in Business, Management and Law 1(1), 68-84.

22) Koh, Hian C. and Larry N. Killough, 1990, The Use of Multiple Discriminant Analysis in the Assessment of the Going Concern Status of an Audit Client, Journal of Business Finance and Accounting 17(2), 179-192.

23) Laitinen, E.K. and T. Laitinen, 2000, Bankruptcy prediction. Application of the Taylor's expansion in Logistic Regression, International Review of Financial Analysis 9, 372- 349.

24) Leland Hayne E. and Klaus Kjerre Toft, 1996, Optimal Capital Structure, Endogenous Bankruptcy, and the Term Structure of Credit Spreads, The Journal of Finance 51(3), 987-1019.

25) Lincoln, M., 1984, An Empirical Study of the Usefulness of Accounting Ratios to Describe levels of Insolvency Risk, Journal of Banking and Finance, 321-340.

26) Hamer, Michelle M., 1983, Failure Prediction: Sensitivity of Classification Accuracy to Alternative Statistical Methods and Variable Sets, Journal of Accounting and Public Policy, 289-308.

27) Martin, D., 1977, Early Warning of Bank Failure, Journal of Banking and Finance 1, 249-276.

28) Gilbert, L.R., K. Menon, and K.B. Schwartz, 1990, Predicting Bankruptcy for Firms in Financial Distress, Journal of Business Finance and Accounting 17(1), 161-171.

29) Ohlson, James A., 1980, Financial Ratios and the Probabilistic Prediction of Bankruptcy, Journal of Accounting Research 18(1), 109-131.

30) Paranjape, Avinash, 1980, Predicting Corporate Sickness: The Case of Indian Textile Industry, FPM Thesis, IIM Ahmedabad.

31) Ramakrishnan, PR, 2003, Corporate Bankruptcy and Restructuring firms in India, Ph.D. Thesis, Department of Commerce, University of 
Madras.

32) Suominen, S. 1988, The Prediction of Bankruptcy in Finland, Studies in Banking and Finance 7, 2736.

33) Taffler, R.J., 1984, Empirical Model for the Monitoring of the U.K. corporations, Journal of Banking and Finance 8(2), 199-227.

34) Tam K. and M. Kiang, 1992, Managerial Application of Neural Networks: The Case of Bank Failure Predictions, Management Science
38(7), 926-947.

35) Zavgren, C., 1983, The Prediction of Corporate Failure: The State of the Art, Journal of Accounting Literature 2, 1-37.

36) Zhongsheng, Hua, Yu Wang, XiaoyanXu, BinZhang and LiangLiang, 2007, Predicting Corporate Financial Distress Based on Integration of Support Vector Machine And Logistic Regression, Expert Systems with Applications 33 (2) 434-440. 